\title{
Impulse Buying Behaviour of Generation Y in Fashion Retail
}

\author{
Nasreen Khan ${ }^{1}$, Lai Hui Hui ${ }^{1}$, Tan Booi Chen ${ }^{1} \&$ Hong Yong Hoe ${ }^{1}$ \\ ${ }^{1}$ Department of Marketing, Faculty of Management, Multimedia University, Malaysia \\ Correspondence: Nasreen Khan, Department of Marketing, Faculty of Management, Multimedia University, \\ Malaysia. E-mail: nasreenkhan88@yahoo.com \\ Received: October 12, 2015 \\ Accepted: October 29, $2015 \quad$ Online Published: December 18, 2015 \\ doi:10.5539/ijbm.v11n1p144 \\ URL: http://dx.doi.org/10.5539/ijbm.v11n1p144
}

\begin{abstract}
Since the past two decades, Generation Y consumers have become global marketers' interest due to their spending power and high likely to engage in impulse buying behaviour. Very little research investigates the impulse buying behaviour of Generation $\mathrm{Y}$ and existing research do not look into the possible factors of impulse buying behaviour as an integrative approach. The main objective of the research is to integrate all the possible factors with its dimensions and examine its simultaneous relationship with impulse buying behaviour. A survey questionnaire was administered to convenient sample of 250 Generation Y consumers of fashion apparel. The results show that demographic factor (gender) has the strongest impact on impulse buying behaviour, followed by situational and personal factors. Interesting finding is that demographic factor (income); situational factor (social influence) and personal factor (extraversion) do not stimulate impulse buying behaviour of Generation Y. These findings may enable global marketers to develop an effective market segmentation strategy.
\end{abstract}

Keywords: situational, personal, demographic, impulse buying behaviour, generation Y, Malaysia

\section{Introduction}

Malaysia is famous as a wonderful shopping place for overseas tourists and as well as for local citizens. Kuala Lumpur, the capital city of Malaysia was ranked as the second top shopping city in Asia-Pacific region in the year of 2012 (Globe Shopper Index, 2013). Many Malaysians are spending their time in shopping mall during public holidays, weekends and even during weekdays (Euro monitor International, 2013). There are approximately 11 million of Generation Y members, cover almost 39 percent from the total population of 28.3 million people (Department of Statistics Malaysia, 2011). Due to the larger size of population are from this generation, marketers must understand the impulse buying behaviour of this cohort. As many of the members in generation $\mathrm{Y}$ are graduates and currently working, their income make them become potential larger buying group. Thus, Generation Y is considered as the most influential group (Kim \& Ammeter, 2008) due to high purchasing power (Krotz, 2005) and significantly buying more often than other generation cohorts (Ma \& Niehm, 2006).

Numbers of research have proved that 62 percent of supermarket revenues are from consumers' impulse buying behaviour and it has significant effect on the sales (Luo, 2005). Although previous research have studied the relationship between impulse buying with some possible factors (Vohs \& Faber, 2007; Yu \& Bastin, 2010), there are still very limited research that integrate all the possible factors with its dimensions and examine its relationship with impulse buying behaviour. Therefore, the objective of the study is to investigate the simultaneous relationship between impulse buying behaviour and its determinant factors.

\section{Literature Review}

Earlier studies defined impulse buying behaviour as unplanned purchase (Clover, 1950) as the consumers have undertaken the purchase action without having purchase intention (Engel et al., 1968). However, many researchers agree that the concept of impulse buying behaviour should not be limited to unplanned purchase but it should also address the effect of exposure to the stimulus and consequently making the decisions on- the-spot (Jones \& Beatty, 1998). Researchers have later realized the importance of behavioural motivation of impulse buying behaviour (Rook \& Hoch, 1985) and introduced the theoretical framework that focus on the drives of impulse buying behaviour. According to the previous findings, situational, personal and demographic factor could be some possible factors that determine the impulse buying behaviour (Armos et al., 2014) however up to date, there is very limited research that examine the simultaneous relationship among these factors with impulse buying behaviour. 


\subsection{Relationship between Situational Factors and Impulse Buying Behaviour}

Situational factors are external stimuli that influence the consumers at the moment of buying on impulse (Kacen et al., 2012). Normally it is not under the control of the consumers but direct influence on impulse buying behaviour. Situational factors are proposed to consist of five dimensions and each dimension i.e. store environment (Liao et al., 2009), social influence (Mattila \& Wirtz, 2008), time (Foroughi et al., 2012), money (Foroughi et al., 2012), and credit card available (Ruzita et al., 2014) has relationship with impulse buying behaviour. Generation Y is likely to buy on impulse provided that they have the time (Ma \& Niehm, 2006), money (Yang et al., 2011) and surrounded in comfortable store environment (Dias, 2003). Besides that, social appropriateness also influences the consumers to engage in impulse buying behaviour (Luo, 2005). Nevertheless, the link between impulse behavior and actual behavior is weakening if a consumer would regard impulse buying behavior as inappropriate due to some reasons. In such situation, even a highly impulsive type of consumer has a smaller probability to follow his urge to buy (Wu \& Huan, 2010).

\subsection{Relationship between Personal and Impulse Buying Behaviour}

Personal factors refer to an individual who has chronic characteristics that reside within the person, and also influence on buying behaviour (Sharma et al., 2010). Past research indicate that personal factors such as mood (Yoon, 2013), hedonic motives (Yu \& Bastin, 2010), lack of control (Shen \& Khalifa, 2012), extraversion (Badgaiyan \& Verma, 2014) and materialism (Bae, 2013) have relationship with impulse buying behaviour (Vohs \& Faber, 2003; Badgaiyan \& Verma, 2014). However, some researchers (Lee, 2008; Eckman \& Yan, 2011) argue that not all personal factors have strong relationship with impulse buying behaviour. For instance, extraverts are more outgoing and likely to engage in impulse behavior compared to others (John \& Srivastava, 1999). Unconformity results rise up questions which dimension of personal factors influence the impulse buying behaviour.

\subsection{Relationship between Demographic Factors and Impulse Buying Behaviour}

Demographic factors such as age, income, gender, education, qualification, marital status and nature of job, have been investigated as influential factors of impulse buying behaviour of consumers in previous studies. Bashar et al. (2013) confirm that the demographic factors influence impulse buying behaviour. Several previous studies have conducted with regards to the role of gender in consumer's behaviour. Those studies found that there is relationship between gender and consumers' impulse buying behaviour; however those findings are inconsistent (Lin \& Lin, 2005). For instance; While Bashar et al. (2013) reports that disposable income has the strongest impact on impulse buying behaviour, Amos et al (2014) argues that income has least influence on impulse buying behaviour.

Although previous studies provide the depth knowledge in understanding the determinant of impulse buying behaviour, the entire research have neglected to consider all these factors as an integrative approach and the literature stream still remain fragmented (Xiao \& Nicholson, 2013). Based on the critiques from past literatures, the study propose that situational, personal and demographic factors influence impulse buying behaviour of Generation Y. Below diagram is proposed framework of the study and hypothesis are developed.

H1: Situation factors (store environment, social influence, time, money and credit card available) influence impulse buying behaviour of Generation Y.

H2: Personal factors (mood, hedonic motive, lack of control, extroversion, materialism) influence impulse buying behaviour of Generation Y.

H3: Demographic factor (gender, income) influence impulse buying behaviour of Generation Y. 


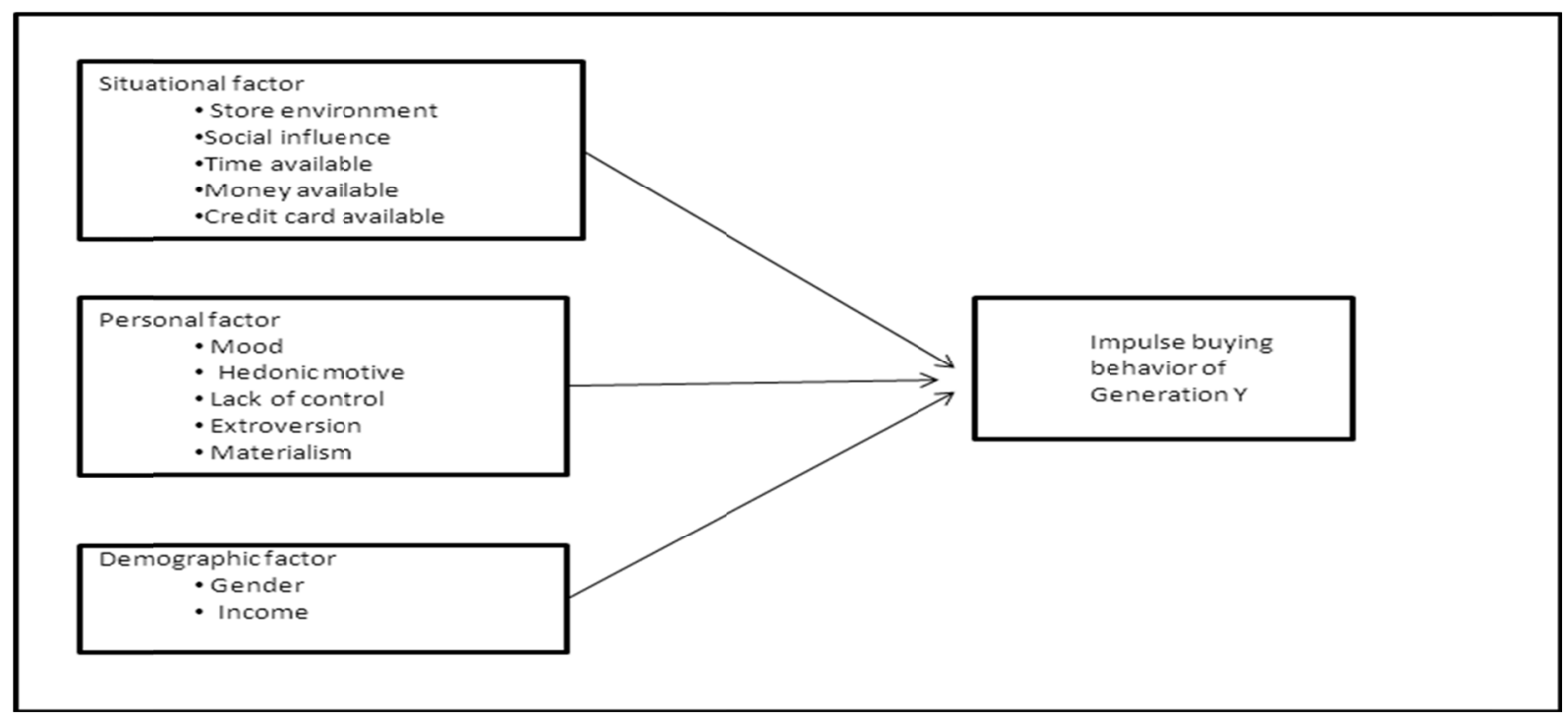

Figure 1. Impulse buying behaviour of generation $\mathrm{Y}$

\section{Research Methodology}

This study is descriptive and causal research in nature. Primary data is used for data collection and questionnaire is distributed to the participants through face to face and e-mail. Targeted populations are Malaysians; belong to Generation Y (born between the years of 1977 to 1995) and the customers of fashion retails in Kuala Lumpur, Malaysia. The sample sizes of 300 respondents are targeted for this research purpose. After screening the collected data, only 250 set of questionnaires were included in the data analysis due to those questionnaires are valid with complete answers. Non- probability sampling method is used because the targeted population in this study is relatively large. This study use cross sectional approach as it is less costly, save time, and convenient. Moreover the data collection process is taken over a limited period of time and the participants' drop- out rate can be minimized. Total of 23 items are used to measure the situational factors which include store environment (Wakefield and Baker, 1998; Chang et al., 2014), social influence (Netemeyer \& Teel, 1989; Mohan et al., 2012), Time (Beatty \& Ferrell, 1998; Chang et al., 2014), money (Rook \& Hoch, 1985; Nor et al., 2014) and credit card available (Hanzaee \& Taherikia, 2010). Total of 27 items are used to measured the personality factors such as mood (Watson et al., 1988; Chang et al., 2014), Hedonic motive (Huasman, 2000; Tifferet \& Herstein, 2012), lack of control (Tellegen, 1982; Badgaiyan \& Verma, 2014), extraversion (Hendriks et al., 1999; Badgaiyan \& Verma, 2014) and materialism (Richins \& Dawson, 1992; Nor at al., 2014). Demographic factor is measured in terms of age and income. Impulse buying behaviour which is measured by 7 items are adapted from Nor et al (2014). Factor analysis, correlation analysis and multiple regression analysis are used to analyse the data.

\section{Analysis and Finding}

Among 250 respondents, $46 \%$ belongs to Chinese, $42 \%$ earn above MYR3000 and 54\% are female. Exploratory factor analysis (EFA) is used to validate factor groupings reflecting underlying theoretical constructs. Results indicate that situation factors which consist of 5 dimensions together explain $68.8 \%$. These dimensions are store environment with $\mathrm{KMO}$ value 0.8 , social influence with $\mathrm{KMO}$ value 0.7 , time available with $\mathrm{KMO} 0.6$, money available with 0.6 and finally credit card available with 0.7 . Whereas, personal factors which consist of 5 dimensions together explain $72.5 \%$ and these dimensions are mood with KMO 0.7, hedonic motive with KMO 0.8 , lack of control with 0.7 , extraversion with 0.8 and materialism with 0.7 . Finally, impulse buying behavior load as single factor with KMO measures 0.8 . The result of Cronbach's alpha reliability analysis clearly show that all the independent variables and dependent variable score 0.7 and above.

\subsection{Pearson Correlation Analysis}

The result from the pearson correlation analysis showed that situational factors $(r=0.35, \mathrm{p}<0.01)$, personal factors $(r=0.39, p<0.01)$ and gender $(r=0.38, p<0.01)$ are significantly positive correlation with impulse buying behaviour of Generation Y. However, income $(r=0.04, p>0.05)$ does not have any relationship with impulse buying behaviour. Among all the variables, personal factors have the strongest relationship with impulse buying behaviour followed by gender and situational factors. The results in table 1 indicate the correlation between 
independent and dependent variables.

Table 1. Pearson correlation analysis

\begin{tabular}{lllll}
\hline \multicolumn{4}{l}{ Dependent variable: Impulse buying behaviour } \\
\cline { 2 - 5 } \multicolumn{1}{l}{ Independent Variables } & $\mathrm{N}$ & $\mathrm{r}$ & Significant \\
\hline Situational Factors & 250 & $0.35^{* * *}$ & 0.000 \\
Personal Factors & 250 & $0.39^{* * *}$ & 0.000 \\
Gender & 250 & $0.38^{* * *}$ & 0.000 \\
Income & 250 & 0.04 & 0.552 \\
\hline
\end{tabular}

***Correlation is significant at the 0.01 level (2-tailed).

\subsection{Multiples Repression Analysis}

The result shows that the model is a good fit with $\mathrm{R}^{2}$ value of 0.59 which is within the range of acceptable value of 0 to 1 . It means that $59 \%$ of impulse buying behaviour of Generation $\mathrm{Y}$ can be explained by three variables which are situational factors (store environment, social influence, time available, money available and credit card available), personal factors (mood, hedonic motive, lack of control, extraversion and materialism) and demographic factors (gender and income). Further detail results indicate that not all the independent variables contribute uniquely to the prediction of score on the impulse buying behaviour of Generation Y. The independents variables such as situational factors $(\mathrm{t}=3.49, \mathrm{p}<0.01)$, personal factors $(\mathrm{t}=3.43, \mathrm{p}<0.01)$ and gender $(\mathrm{t}=5.82, \mathrm{p}<0.01)$ significantly influence the impulse buying behaviour. However, income $(\mathrm{t}=-0.4, \mathrm{p}>0.01)$ does not contribute to impulse buying behaviour. The results in table 2 indicate the multiple regression analysis of independent and dependent variables.

Table 2 Multiples repression analysis

\begin{tabular}{|c|c|c|c|}
\hline \multirow{2}{*}{\multicolumn{4}{|c|}{ Dependent variable: Impulse buying behaviour }} \\
\hline & & & \\
\hline Independent Variables & Beta & $\mathrm{t}$ & Significant \\
\hline Situational Factors (SF) & 0.24 & 3.49 & 0.001 \\
\hline Personal Factors (PF) & 0.22 & 3.43 & 0.001 \\
\hline Gender & 0.32 & 5.82 & 0.000 \\
\hline Income & -0.02 & -0.40 & 0.691 \\
\hline
\end{tabular}

***Correlation is significant at the 0.01 level (2-tailed).

Further analysis is carried out to test the relationship between dimensions of each factor with impulse buying behaviour. Result shows that situation factors such as store environment $(\mathrm{t}=4.79, \mathrm{p}<0.01)$, time available $(\mathrm{t}=$ 2.72, $\mathrm{p}<0.01)$, money available $(\mathrm{t}=2.35, \mathrm{p}<0.01)$ and credit card available $(\mathrm{t}=6.98, \mathrm{p}<0.01)$ influence the impulse buying behaviour but social influence $(\mathrm{t}=0.28, \mathrm{p}>0.01)$ does not have any impact. Personal factors such as mood $(\mathrm{t}=-2.21, \mathrm{p}<0.010)$, hedonic motive $(\mathrm{t}=4.84, \mathrm{p}<0.01)$, lack of control $(\mathrm{t}=4.33, \mathrm{p}<0.01)$ and materialisms $(\mathrm{t}=8.33, \mathrm{p}<0.01)$ impact on impulse buying behaviour however, extroversion $(\mathrm{t}=-1.38, \mathrm{p}>0.01)$ does not have any effect. Regarding the demographic factors, gender $(t=5.82, p<0.01)$ has positive influence on impulse buying behaviour but income $(t=-0.4, \mathrm{p}>0.01)$ does not contribute to stimulate the impulse buying behaviour.

\section{Discussion and Conclusion}

General objective of the study is to examine the simultaneous relationship between impulse buying behaviour of Generation $\mathrm{Y}$ and its determinant factors i.e. situation, personal and demographic. Among all the factors, demographic factor (gender) has strongest impact on impulse buying behaviour, followed by situational and personal factors. Thus, the retailers should develop effective marketing strategy based on the gender group. Among all the dimensions of situational factors; store environment, money availability and credit card availability, time availability influence the impulse buying behaviour but social influence does not have any effect. The result revealed that presence of either friends or family do not influence the generation $Y$ to engage in impulse buying behaviour and this finding is consistent with the previous research findings (Graa \& Dani-elkabir, 2011). Therefore, marketers have to promote store environment in terms of music, lightings, appropriate temperature, creative layout and design, arrange easy payment with both credit and debit card and also offer 
limited time for attractive promotion would help in stimulating impulse buying behaviour of Generation Y.

Regarding the personal factors; lack of control, hedonic motive, materialism and good mood, stimulate impulse buying behaviour. Among all the dimensions, materialism has the strongest impact on impulse buying behaviour. This result is different from the previous research finding in which Chavosh et al. (2011) confirms that there is no relationship between materialism and impulse buying behaviour. Justification behind the finding of materialism has the strongest impact on impulse buying behaviour is, most probably due to the generation Y's consciousness in improving their self image and social identify though changing trends of fashion apparel. In addition, they are fashion conscious and they tend to be more fascinated by fashion apparel, (Pentecost \& Lynda, 2010). In contrast, extraversion does not have any impact on impulse buying behaviour but the result is contrary to the previous research findings (Mathai \& Haridas, 2014). To target the Generation Y effectively, marketers must have a unique way in segmenting the market by being aware of constantly changing the attitudes and trends in this generation (Hughes, 2008).

When come to further testing on demographic factors with impulse buying behaviour; females are more likely to engage in impulse buying behaviour compare to males. This result has given a sight for the retailers who target their potential consumers by using gender. Finding further reveal that income does not stimulate the impulse buying behaviour. The reason behind would be that generation $\mathrm{Y}$ consumers typically spend their cash promptly compare to other generations. They are individualistic and have full of self-confidence (Laermer \& Simmons 2007).

In conclusion, this study represents an effort to provide an integrative view of impulse buying behavior by examining the multi- dimension factors that influence impulse buying behavior of Generation Y. The foremost contribution of this study to academia is integrative view of the factors such as situational, personal, and demographic factors with its dimensions that influence the Generation Y's impulse buying behaviour.

\section{Limitation and Future Research}

Limitation of the study regards to sample size and composition of data that had been collected. The data collection is restricted and the sample size of 250 numbers of participants is relatively small in representing the approximately 11 million population of Malaysian Generation Y. Due to limited time and cost, the convenient sampling methods is used and the distribution of questionnaire is through email and face to face distribution in Kuala Lumpur, Malaysia. Therefore, the result obtained from this study might not reflect the entire population of Malaysian. Future research should consider larger sample sizes that extract from the whole state of Malaysia.

\section{References}

Amos, C., Holmes, G. R., \& Keneson, W. C. (2014). A meta- analysis of consumer impulse buying. Journal of Retailing and Consumer Services, 21, 86-97. http://dx.doi.org/10.1016/j.jretconser.2013.11.004

Badgaiyan, A. J., \& Verma, A. (2014). Intrinsic factors affecting impulsive buying behaviour-Evidencefrom India. Journal of Retailing and Consumer Services, 21, 537-549. http://dx.doi.org/10.1016/j.jretconser.2014.04.003

Bae. (2013). Understanding Ethical Consumers: Assessing the Moderating Effects of Price Sensitivity, Materialism, Impulse Buying Tendency, and Clothing Involvement (Doctoral Dissertation, Colorado State University).

Bashar, A., Ahmad, I., \& Wasiq, M. (2013). A study of influence of demographic factors on consumer impulse buying behavior. Journal of Management Research, 13(3), 145-154. http://dx.doi.org/10.1086/209186

Bearden, W. O., Netemeyer, R. G., \& Teel, J. E. (1989). Measurement of Consumer Susceptibility to Interpersonal $\begin{array}{lllll}\text { Influence. Journal of Consumer } & \text { Research, } & \text { 15(4), }\end{array}$ http://dx.doi.org/10.1016/S0022-4359(99)80092-X

Beatty, S. E., \& Ferrell, M. E. (1998). Impulse Buying: Modeling Its Precursors. Journal of Retailing, 74(2), 169-191. http://dx.doi.org/10.1016/S0022-4359(99)80092-X

Chang, H. J., Eckman, M., \& Yan, R. N. (2011). Application of the Stimulus-Organism-Response model to the retail environment: the role of hedonic motivation in impulse buying behavior. The International Review of Retail, Distribution and Consumer Research, 21(3), 233-249. http://dx.doi.org/10.1080/09593969.2011.578798

Chang, H. J., Yan, R. N., \& Eckman, M. (2014). Moderating effects of situational characteristics on impulse buying. International Journal of Retail \& Distribution Management, 42(4), 298-314. http://dx.doi.org/10.1108/IJRDM-04-2013-0074 
Chavosh, A., Halimi, A. B., \& Namdar, J. (2011). The contribution of product and cons umer characteristics to consumer's impulse purchasing behavior in Singapore. Proceedings of International Conference on Social Science and Humanity (pp. 248-252). Singapore: IACSIT Press.

Clover, V. T. (1950). Relative importance of impulse-buying in retail stores. The Journal of Marketing, 15(1), 66-70. http://dx.doi.org/10.2307/1247083

Department statistics Malaysia. (2011). Population Distribution and Basic Demographic Characteristics Report 2010. Retrieved from http://www.Statistics.gov.my/portal/index.php?option=com_content\&id=1215

Dias, L. P. (2003). Generational buying motivations for fashion. Journal of Fashion Marketing and Management, 7(1), 78-86. http://dx.doi.org/10.1108/13612020310464386

Engel, J. F., Kollat, D. T., \& Blackwell, R. D. (1968). Consumer behavior. New York: Holt, Rinehart \& Winston.

Euromonitor International. (2013). Retailing in Malaysia.

Foroughi, A., Buang, N. A., \& Sadeghi, R. H. M. (2012). Exploring the influence of situational factors (money \& time available) on impulse buying behaviour among different ethics. International Journal of Fundamental Psychology \& Social Sciences, 2(2), 41-44.

Globe Shopper Index. (2013). Globe Shopper Index-Asia-Pacific. Retrieved from

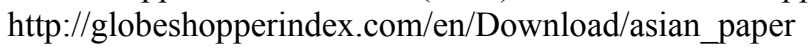

Graa, A., \& Dani-elkabir, M. (2011). Situational factors influencing impulse buying behaviour of Algerian Consumer. Romanian Journal of Marketing, 4(2), 52-59.

Hanzaee, K. H., \& Taherikia, F. (2010). Impulse buying: An Iranian model China-USA Business Review.

Hausman, A. (2000). A multi-method investigation of consumer motivations in impulse buying behavior. Journal of Consumer Marketing, 17, 403-426. http://dx.doi.org/10.1108/07363760010341045

Hendriks, A. A. J., Hofstee, W. K. B., \& De Raad, B. (1999). The Five-Factor Personality Inventory (FFPI). Personality and Individual Differences, 27, 307-325. http://dx.doi.org/10.1016/S0191-8869(98)00245-1

Hughes, A. (2008). Y and how: Strategies for reaching the elusive Generation Y consumer. Honours College Theses. Retrieved from http://digitalcommons.pace.edu/honorscollege_theses/74

John, O. P., \& Srivastava, S. (1999). The Big-Five trait taxonomy: History, measurement, and theoretical perspectives in Handbook of personality: Theory and research. Guilford, New York.

Jones, M. A., Reynolds, K. E., Weun, S., \& Beatty, S. E. (2003). The product-specific nature of impulse buying tendency. Journal of Business Research, 56(7), 505-512. http://dx.doi.org/10.1016/S0148-2963(01)00250-8

Kacen, J. J., Hess, J. D., \& Walker, D. (2012). Spontaneous selection: the influence of product and retailing factors on consumer impulse purchases. Journal of Retailing Consumer Services, 19, 578-588. http://dx.doi.org/10.1016/j.jretconser.2012.07.003

Kim, D., \& Ammeter, A. P. (2008). Examining shifts in online purchasing behavior: Decoding the 'net generation. Academy of Information and Management Sciences, 12(1), 7-12.

Krotz, J. L. (2005). Tough customers: How to reach Gen Y. Microsoft Small Business Center, Redmond, WA.

Laermer, R., \& Simmons, M. (2007). Punk marketing. New York: Harper Collins.

Lee, J. (2008). Relative and interaction effects of situational and personal factors on impulse buying (Doctoral Dissertation, University of Minnesota).

Liao, S. L., Shen, Y. C., \& Chu, C. H. (2009). The effects of sales promotion strategy, product appeal and consumer traits on reminder impulse buying behaviour. International Journal of Consumer Studies, 33, 274-284. http://dx.doi.org/10.1111/j.1470-6431.2009.00770.x

Lin C. H. \& Lin H. M. (2005). An Exploration of Taiwanese Adolescents' Impulsive Buying Tendency. Adolescence, 40(157), 215-223.

Luo, X. M. (2005). How Does Shopping with Others Influence Impulsive Purchasing? Journal of Consumer Psychology, 15(4), 288-294. http://dx.doi.org/10.1207/s15327663jcp1504_3

Ma, Y. J., \& Niehm, L. S. (2006). Service expectations of older Generation Y customers: An examination of apparel retail settings. Managing Service Quality, 16(6), 620-640. http://dx.doi.org/10.1108/09604520610711936 
Mathai, S. T., \& Haridas, R. (2014). Personality-its impact on impulse buying behaviour among the retail customers in Kochin city. Journal of Business and Management, 16(4), 48-55.

Mattila, A. S., \& Wirtz, J. (2001). Congruency of Scent and Music as a Driver of in store Evaluations and Behavior. Journal of Retailing, 77, 273-289. http://dx.doi.org/10.1016/S0022-4359(01)00042-2

Mohan, G., Sivakumaran, B., \& Sharma, P. (2012). Store environment' s impact on variety seeking behavior. $\begin{array}{lllll}\text { Journal of Retailing and Consumer } & \text { Services, } & \text { 19, }\end{array}$ http://dx.doi.org/10.1016/j.jretconser.2012.04.003

Nor, A. O., Ruzita, A. R., Che, A. C. W., \& Syer, S. A. (2014). Compulsive buying and credit card misuse among credit card holders: the role of self esteem, materialism, impulsive buying and budget constraint. Intangible Capital, 10(1), 52-74.

Pentecost, R., \& Andrews, L. (2010). Fashion retailing and the bottom line: The effects of the generational cohorts, gender, fashion fanship, attitudes and impulse buying on fashion expenditure. Journal of Retailing and Consumer Services, 17(1), 42-52. http://dx.doi.org/10.1016/j.jretconser.2009.09.003

Richins, M. L., \& Dawson, S. (1992). A Consumer Values Orientation for Materialism and Its Measurement: Scale Development and Validation. Journal of Consumer Research, 19, 303-316. http://dx.doi.org/10.1086/209304

Rook, D., \& Hoch, S. (1985). Consuming impulses. Advances in Consumer Research, 7(1), 23-27.

Sharma, P., Sivakumaran, B., \& Marshall, R. (2010). Impulse buying and variety seeking: A trait correlates perspective. Journal of Business Research, 63(3), 276-283. http://dx.doi.org/10.1016/j.jbusres.2009.03.013

Shen, K. N., \& Khalifa, M. (2012). System design effects on online impulse buying. Internet Research, 22(4), 396-425. http://dx.doi.org/10.1108/10662241211250962

Tellegen, A. (1982). Brief Manual for the Multidimensional Personality Questionnaire. University of Minnesota, Unpublished Manuscripts.

Tifferet, S., \& Herstein, R. (2012). Gender differences in brand commitment, impulse buying, and hedonic consumption. Journal of Product \& Brand Management, 21(3), 176-182. http://dx.doi.org/10.1108/10610421211228793

Vohs, K., \& Faber, R. (2003). Self-Regulation and Impulsive Spending Patterns. Advances in Consumer Research, 30(1), 125. http://dx.doi.org/10.1086/510228

Vohs, K. D., \& Faber, R. J. (2007). Spent Resources: Self-Regulatory Resource Availability Affects Impulse Buying. Journal of Consumer Research, 33(4), 537-547.

Wakefield, K. L., \& Baker, J. (1998). Excitement at the Mall: Determinants and Effects on Shopping Response. Journal of Retailing, 74(4), 515-39. http://dx.doi.org/10.1016/S0022-4359(99)80106-7

Watson, D., Clark, L. A., \& Tellegen, A. (1988). Development and validation of brief measures of positive and negative affect: The PANAS scales. Journal of Personality and Social Psychology, 54(6), 1063-1070. http://dx.doi.org/10.1037/0022-3514.54.6.1063

Wu, W. C., \& Huan, T. C. (2010). The effect of purchasing situation and conformity behavior on young students' impulse buying. African Journal of Business Management, 4(16), 3530-3540.

Xiao, S. H., \& Nicholson, M. (2013). A Multidisciplinary Cognitive Behavioural Framework of Impulse Buying: A Systematic Review of the Literature. International Journal of Management Reviews, 15(3), 333-356. http://dx.doi.org/10.1111/j.1468-2370.2012.00345.x

Yang, D. J., Huang, K. C., \& Feng, X. (2011). A study of the factors that affect the impulsive cosmetics buying of female consumers in Kaohsiung. International Journal of Business and Social Science, 2(24), 275-282.

Yoon, S. J. (2013). Antecedents and consequences of in-store experiences based on an experiential typology. European Journal of Marketing, 47(5/6), 693-714. http://dx.doi.org/10.1108/03090561311306660

Yu, C., \& Bastin, M. (2010). Hedonic shopping value and impulse buying behavior in transitional economies: A symbiosis in the Mainland China marketplace. Journal of Brand Management, 18(2), 105-114. http://dx.doi.org/10.1057/bm.2010.32 


\section{Copyrights}

Copyright for this article is retained by the author(s), with first publication rights granted to the journal.

This is an open-access article distributed under the terms and conditions of the Creative Commons Attribution license (http://creativecommons.org/licenses/by/3.0/). 